\title{
PROGRAM KOEKSISTENSI MANUSIA DENGAN ORANGUTAN BORNEO DI HUTAN LINDUNG SAMBOJA LESTARI, KUTAI KARTANEGARA, KALIMANTAN TIMUR
}

\author{
Nadia Erica Hindrakusuma ${ }^{1)}$, Nina Carina ${ }^{2)}$ \\ 1) Program Studi S1 Arsitektur, Fakultas Teknik, Universitas Tarumanagara, nadddericaaa@gmail.com \\ 2) Program Studi S1 Arsitektur, Fakultas Teknik, Universitas Tarumanagara, ninac@ft.untar.ac.id
}

Masuk: 03-07-2021, revisi: 09-08-2021, diterima untuk diterbitkan: 23-10-2021

\begin{abstract}
Abstrak
Bertambahnya jumlah manusia berdampak pada penambahan kebutuhan tempat tinggal, sehingga terjadi ekspansi permukiman manusia ke seluruh penjuru Bumi. Pada satu titik, pembangunan tersebut dapat memasuki ranah habitat dan konservasi satwa liar yang dapat merugikan baik bagi upaya konservasi alam, maupun bagi keberlangsungan kehidupan manusia. Fenomena tersebut dapat diprediksikan terjadi pada rencana pembangunan IKN (Ibu Kota Negara) Indonesia baru di Penajam Paser Utara dan Kutai Kartanegara, Kalimantan Timur, dimana salah satu spesies endemik terancam punah Indonesia berada, yaitu Orangutan Borneo.Usulan proyek eksperimental koeksistensi antar spesies ini diharapkan dapat menjadi $d$ welling bagi manusia yang kian berkembang untuk belajar melindungi dan memahami Orangutan, dimana proyek ini juga sebagai salah satu fasilitas pendukung upaya konservasi in situ di hutan lindung Samboja Lestari. Metode yang digunakan berupa bio-inspired dari cara hidup Orangutan yang lebih bijak dalam hidup di hutan hujan tropis. Hasil dari desain berupa unit-unit dwelling moduler bagi ilmuwan, eco-tourist/relawan lingkungan, dan pelajar; dikonfigurasikan agar dapat memenuhi kebutuhan ruang baik bagi manusia maupun satwa liar. Kata Kunci: Dwelling Moduler; IKN Baru; Koeksistensi antar Spesies; Konservasi; Orangutan Borneo.
\end{abstract}

\begin{abstract}
The increase in human population directly impacts the rise of housing needs, resulting in the expansion of human development to other parts of the planet. At some point, these developments might enter wildlife habitats and conservation areas which could cause harm to conservation efforts and the general livelihood of the people. This phenomenon can be expected to occur in the development of Indonesia's New Capital in North Penajam Paser and Kutai Kartanegara, East Kalimantan, where one of Indonesia's endemic and critically endangered species makes their home, the Bornean Orangutans. The idea of this experimental project of human-wildlife coexistence gives hope as dwellings for the ever-growing human population while learning to protect and connect with the Orangutans, which also doubles as an in-situ conservation facility in the sanctuary forest of Samboja Lestari. The design method used is bioinspired by the Orangutans' wisdom in the ways of the tropical rainforest. The design produces modular dwelling units for researchers, eco-tourist/volunteers, and students; configured to fulfill the spatial needs for both human and wildlife users.
\end{abstract}

Keywords: Bornean Orangutans; Conservation; Inter-species Coexistence; Modular Dwellings; New Capital.

\section{PENDAHULUAN}

\section{Latar Belakang}

Bertambahnya jumlah manusia di Bumi akan membawa juga penambahan pada kebutuhan tempat tinggal dan berhuni, sehingga akan terjadi ekspansi dan development permukiman manusia ke seluruh penjuru Bumi. Pada satu titik, pembangunan tersebut dapat memasuki ranah habitat dan lahan konservasi hewan liar, sehingga dapat memicu konfilk antar manusia - hewan liar. Hal ini dapat merugikan baik bagi upaya konservasi alam, maupun bagi keberlangsungan kehidupan manusia. 
Fenomena tersebut dapat diprediksikan terjadi pada rencana pembangunan IKN (Ibu Kota Negara) Indonesia yang baru di Penajam Paser Utara dan Kutai Kartanegara, Kalimantan Timur. Kondisi Jakarta saat ini yang padat populasi menjadi salah satu faktor pendukung beralihnya IKN ke Kalimantan Timur. Namun pembangunan IKN di Kalimantan Timur sendiri menimbulkan masalah-masalah baru, terutama berdampak pada ekosistem. Lahan sebesar 160.000 Ha yang bertitik nol pada Desa Pemaluan, Sepaku, Penajam Paser Utara, menjadi lokasi pembangunan IKN baru. Meskipun Ground Breaking proyek IKN baru dilaksanakan pada Oktober 2020 silam, dapat terlihat dampak lingkungan, yaitu land-clearing secara besar-besaran pada area yang sebelumnya merupakan bagian dari ekosistem Borneo Lowland Rainforest. Menurut data HOB Report oleh WWF (2016), lahan sekitar titik nol IKN baru merupakan habitat bagi berbagai macam spesies endemik, bahkan mencangkup beberapa spesies dalam program konservasi yang terancam punah.

Dari fenomena tersebut, timbul pertanyaan mengenai pembangunan manusia pada area yang akan menjadi Urban-Wildlife Interface tersebut. Selama ini, manusia membangun habitat eksklusif dengan jadwal yang antroposentris. Namun pada area pertemuan ini, perlu sebuah approach baru dalam membangun, yang tidak hanya dapat menjadi rumah bagi manusia, tetapi juga menjadi rumah bagi spesies lainnya yang telah berhuni sejak sebelum kedatangan manusia di habitatnya. Sehingga ketika manusia kembali ke dalam jaringan ekosistem yang kompleks tersebut, diharapkan dapat berkontribusi secara positif ke dalam lingkungan yang menjadi tempatnya membangun.

\section{Rumusan Permasalahan}

Bertambahnya populasi manusia pada Kalimantan Timur akibat pembangunan IKN baru akan berdampak pada terbentuknya ruang-ruang khusus bagi manusia yang memungkinkan merambah ke habitat hewan-hewan liar endemik yang bahkan terancam punah. Proyek ini dirancang untuk menjadi contoh desain yang dapat menjadi rumah yang inklusif baik bagi manusia maupun satwa endemik, terutama yang menjadi subyek konservasi. Lewat program-program yang ditawarkan, diharapkan dapat membuka interaksi baru antar manusia dengan satwa liar endemik yang berdampak positif bagi upaya konservasi satwa tersebut. Dalam konteks IKN baru, satwa liar yang paling terancam adalah Orangutan Borneo sehingga satwa tersebut menjadi fokus dalam proyek ini.

\section{Tujuan}

Tujuan proyek ini adalah memunculkan desain dwelling yang dapat menunjang keberlangsungan hidup bagi manusia dan satwa liar endemik pada IKN baru, terutama satwa Orangutan Borneo yang terancam punah. Dengan program yang dapat memberikan dampak positif bagi hubungan manusia dan satwa liar, diharapkan dapat membantu upaya konservasi in-situ Orangutan Borneo.

\section{KAJIAN LITERATUR}

\section{Ekologi}

Istilah ekologi pertama kali dicetuskan pada tahun 1866 oleh ilmuwan asal Jerman, Ernst Haeckel. Ekologi merupakan sebuah bidang ilmu yang mempelajari organisme dan hubungannya dengan organisme lain dan lingkungan hidupnya (McManus, 2009: 294). Ekologi berasal dari bahasa Yunani

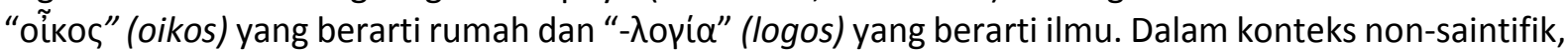
Ekologi digunakan untuk memberikan penekanan pada pentingnya hubungan antar organisme dan dampak (sebab-akibat) dari interaksi tersebut. Meskipun ekologi seringkali dipahami sebagai cabang dari ilmu biologi, ekologi merupakan kolaborasi dari berbagai cabang ilmu (geologi, sosiologi, zoologi, filosofi, dsb.) yang bertujuan memahami secara holistik bagaimana hubungan antar makhluk hidup terjalin. 


\section{Habitat}

Dalam ilmu ekologi, habitat adalah lingkungan fisik yang ada di sekitar suatu sepseis, atau populasi, atau kelompok spesies, atau komunitas (Clements dan Shelford, 1939). Sebuah habitat mampu memenuhi segala kebutuhan organisme untuk bertahan hidup di dalamnya.

Secara garis besar, faktor yang mempengaruhi terbentuknya suatu habitat dapat dibagi menjadi: a.faktor abiotik :intensitas cahaya, ketersediaan air, kelembaban udara, salinitas, pH lingkungan, suhu udara, dsb., b.faktor biotik :predator, ketersediaan mangsa, sumber makanan, parasit, penyakit/virus, dsb..

Terdapat 4 komponen utama dalam pembentukan suatu habitat yaitu sebagai berikut (Dunn, 1993).

a.Space: Space atau keperluan ruang masing-masing species dapat bervariasi. Contoh : pada koloni semut pemotong daun hanya perlu beberapa sq inch untuk membentuk liang tanah, menemukan makanan, dsb. sementara seekor puma yang merupakan predator teritorial soliter memerlukan sekitar $455 \mathrm{~km}^{2}$ ruang untuk berburu makanan, berkembang biak, dsb.

b.Food: Ketersediaan makanan yang seimbang menjadi salah satu kunci keberlangsungan hidup species.

c.Water: Tiap makhluk hidup memerlukan asupan hidrasi meskipun kebutuhan masing-masing spesies berbeda.

d.Shelter: Shelter menyediakan proteksi dari predator dan elemen alam, serta tempat tidur, makan, berkembang biak, dsb. Shelter dalam dapat hadir dalam berbagai bentuk dan 1 shelter dapat menaungi beberapa jenis species. Contoh : dalam sebuah pohon di biome hutan hujan, dapat menyediakan shelter bagi ulat bulu pada daun, bagi fungus di akar yang lembab, bagi elang di puncak-puncak kanopi.

\section{Biodiversitas}

Menurut Sudarsono dkk (2005: 6), biodiversitas atau keanekaragamaan hayati adalah ketersediaan keanekaragaman sumber daya hayati berupa jenis maupun kekayaan plasma nutfah (keberagaman genetik dalam satu spesies), keanekaragaman antarjenis, dan keanekaragaman ekosistem. Biodiversitas merupakan kodrat alam yang memiliki nilai intrinsik, dimana tiap spesies memiliki nilai dan hak untuk hidup, baik memberikan keuntungan bagi manusia mupun tidak.

Meskipun terlepas dari human value, biodiversitas tetap memberikan benefit bagi kehidupan manusia. The biodiversity book by the Commonwealth Scientific and Industrial Research Organisation (CSIRO; Morton \& Hill, 2014) mendeskripsikan 5 nilai dasar manfaat biodiversitas bagi manusia.

a.Economic: Biodiversitas menyediakan manusia material mentah untuk diproduksi dan dikonsumsi secara bertanggung jawab.

b.Ecological Life Support: Biodiversitas menunjang ekosistem yang berfungsi dengan baik, menyediakan oksigen, udara dan air bersih, polinasi tumbuhan, kontrol hama, pengolahan air alami. c.Recreation: Kegiatan rekreasi alam banyak yang dilakukan beradasarkan biodiversitas, seperti birdwatching, hiking, berkemah, memancing, dsb.

d.Cultural: Budaya banyak negara, termasuk Indonesia sangat dekat dengan adanya biodiversitas, lewat ekspresi identitas, spiritualitas, dan apresiasi kekayaan alam nusantara.

e.Scientific: Biodiversitas mewakilkan kekayaan data ekologi yang sistematis dan dapat membantu manusia memahami lebih dalam tentang alam semesta dan asal usulnya. 


\section{Biodiversitas di Provinsi Kutai Kertanegara Kalimantan Timur}

Gambar 1. Lokasi Ibu Kota Negara Baru Indonesia berada di provinsi Kalimantan Timur Sumber: Reuters, 2019

Kalimantan Timur merupakan provinsi terpilih untuk IKN Baru Indonesia, dengan konstruksi yang dimulai pada tahun 2020 dan diharapkan selesai dalam 5 tahun kedepan. Mencangkup daerah timur pulau Borneo, dengan populasi sekitar 3,6 juta jiwa (proyeksi pertengahan tahun 2019). Ibu Kota provinsi saat ini adalah Samarinda. Provinsi Kalimantan Timur seluas $125.336,81 \mathrm{~km}^{2}$ dengan lautan seluas $25.656 \mathrm{~km}^{2}$. I klim tropis di Kalimantan Timur memiliki suhu pada kisaran $21,6^{\circ} \mathrm{C}-35,6^{\circ} \mathrm{C}$ dengan kelembaban udara rata-rata $83-87 \%$ (data tahun 2013).

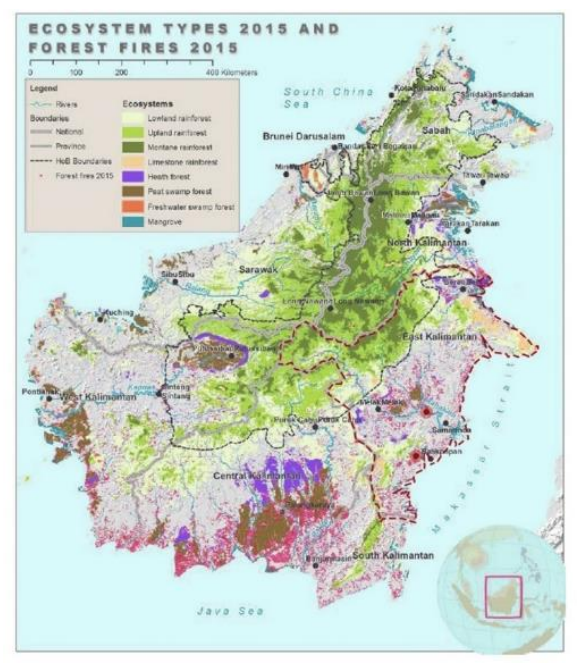

Gambar 2. Persebaran jenis ekosistem di Borneo. Pada daerah sekitar IKN baru, Ekosistem yang dominan ditemui adalah Lowland dan Upland Rainforest. Ekosistem ini mencangkup beberapa hutan lindung di sekitar lokasi IKN baru.

Sumber: WWF HOB Environmental Report, 2016

Ibukota baru yang mencangkup beberapa bagian dari provinsi Kutai Kertanagara ini membentuk sebuah tipologi urban baru yaitu Forest Archipelago City, dimana zoning-zoning pada ibukota menyerupai kepulauan yang menyebar di tengah hutan. Namun gagasan ini justru mengundang kritik dari beberapa pihak, terutama mengenai ecological impact. Meskipun pembangunan IKN baru saat ini berada pada lokasi non-konservasi, namun keberadaan IKN akan memicu berbagai jenis urban growth yang pada suatu saat dapat merambah ke area konservasi dan pelestarian hutan hujan. 


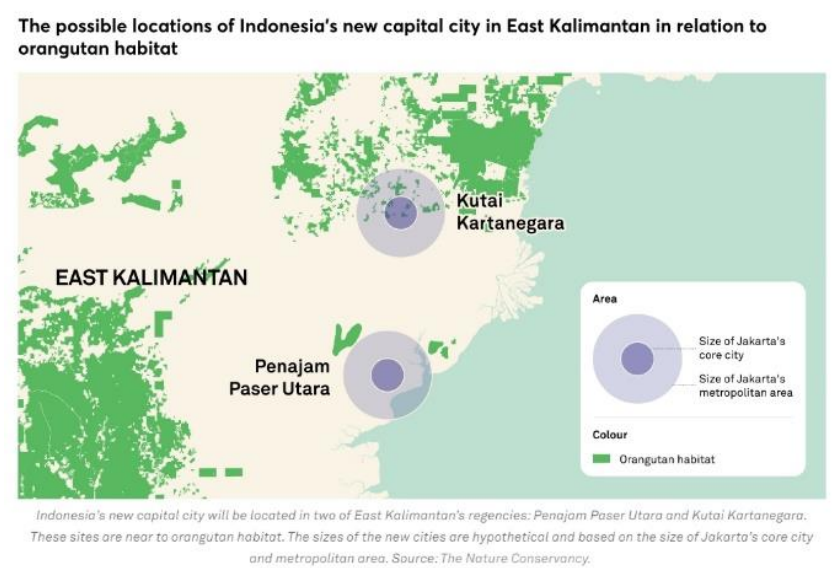

Gambar 3. Kawasan konservasi Orangutan sangat dekat dengan kawasan pengembangan IKN baru Sumber: Kontinentalist, 2021

\section{Orangutan Borneo}

Orangutan Borneo merupakan mamalia arboreal (hidup di pepohonan) terbesar di dunia, meskipun beberapa kegiatan kehidupan tetap dilkukan di lantai hutan (Ancrenaz et al., 2014). Orangutan Borneo merupakan satwa omnivora yang mengonsumsi buah-buahan, dedaunan, dahan, bunga, dan serangga (Russon et al., 2009). Orangutan Borneo hidup semi-solitary, biasanya hanya bersosialisasi untuk berkembang biak, terkadang berbagi makanan. Per harinya, Orangutan Borneo memerlukan 15-20 hektare sebagai daerah teritorial, tergantung kondisi hutan dan ketersediaan makanan. Kecepatan reproduksi Orangutan Borneo cenderung lambat (rata-rata melahirkan 1 anak tiap 6-8 tahun) dengan masa tumbuh (hingga mencapai maturity) pada 10-15 tahun.

Jumlah total Orangutan Borneo tidak persis diketahui, namun estimasi pada tahun 2004 mengatakan ada sekitar 104.700 di landmass Borneo (Wich et al., 2012). Dengan tingkat penurunan populasi yang sekarang, diproyeksikan populasi Orangutan Borneo dapat menurun ke 47.000 ekor pada tahun 2025. Digabungkan dengan hilangnya habitat, survey di Kalimantan pada tahun 2011 oleh Meijaard et al. menyimpulkan bahwa 2.000-3.000 ekor Orangutan mati tiap tahun dalam kisaran 40 tahun terakhir, dan bila hal ini terus terjadi, maka spesies ini mungkin punah pada 50 tahun kedepan (Abram et al., 2015).
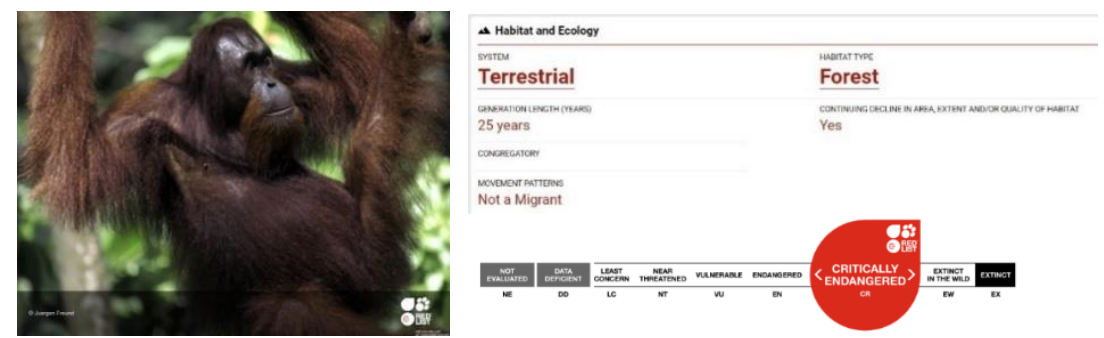

Gambar 4. Status konservasi Orangutan Borneo saat ini mencapai Critically Endangered pada IUCN Red List, dengan populasi yang semakin menurun tiap tahunnya. Sumber: IUCN Red List, 2021

\section{Upaya Konservasi Orangutan Borneo}

Terdapat beberapa upaya konservasi Orangutan Borneo yang melibatkan organisasi lingkungan seperti BOSF (Borneo Orangutan Survival Foundation) dan WWF (World Wildlife Fund). BOSF memiliki fasilitas rehabilitasi Orangutan Borneo di kawasan Samboja, Kutai Kartanegara, Kalimantan Timur, dengan program rehabilitasi (karantina, Kesehatan, suaka jangka panjang) dan bertujuan mereintroduksi Orangutan ke hutan-hutan di HOB. 


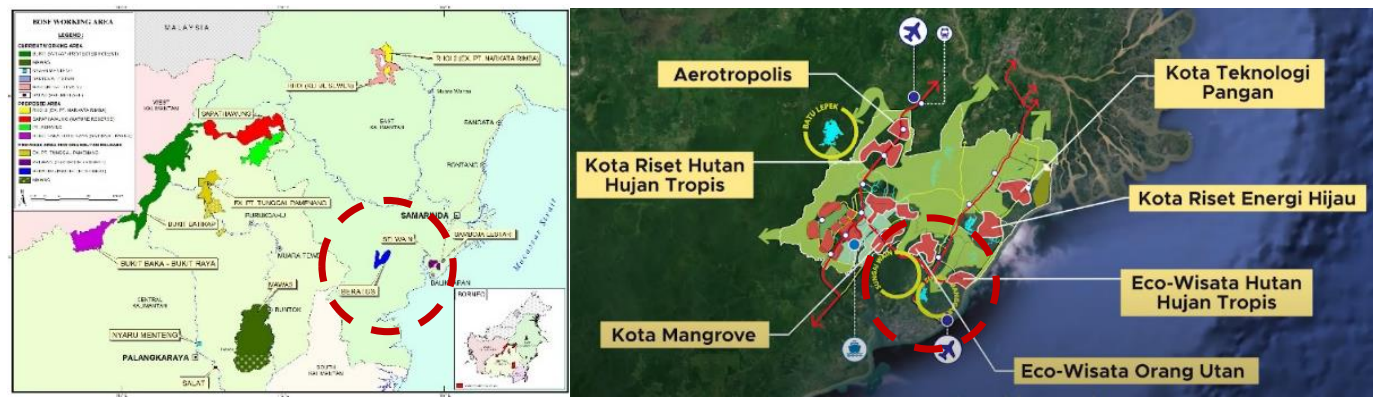

Gambar 5. BOSF Samboja Lestari menjadi bagian dari area pengembangan IKN Baru.

Sumber: BOSF, 2010; Kementrian PUPR, 2020

Meskipun proses penyelamatan dan rehabilitasi dapat berjalan dengan lancar, terdapat beberapa faktor yang dapat membuat Orangutan Borneo tidak dapat dilepaskan kembali ke habitat alaminya. Hal ini meliputi luka fisik dan disabilitas, kemampuan atau naluri survival yang tidak dapat diproleh lewat rehabilitasi, penyakit, atau perilaku bermasalah lainnya. Orangutan un-releasable BOSF saat ini hidup dalam kandang-kandang rehabilitasi. Sejak 2017, BOSF telah berupaya membebaskan Orangutan ini pada artificial islands yang terletak pada pusat hutan lindung Samboja Lestari. Namun dengan meningkatnya aktivitas manusia yang dapat menimbulkan trauma bagi Orangutan sehingga menjadi un-releasable, diperlukan opsi-opsi baru dalam membebaskan Orangutan yang tidak mampu bertahan hidup di hutan rimba tersebut.

Pada tahun 2019, 81 dari 93 orangutan unreleasable pada Samboja Lestari masih tinggal di dalam kandang penangkaran. Salah satu goal dari BOSF adalah Freedom for All, termasuk orangutan unreleasable ini. Setidaknya bagi orangutan unreleasable untuk hidup semi-wild dalam kawasan hutan lindung yang mendekati habitat asli namun masih dalam pantauan manusia.

\section{Koeksistensi antara Satwa Liar dan Manusia}

Pembangunan IKN baru di Penajam Paser Utara dan Kutai Kartanagara, Kalimantan Timur, akan meningkatkan interaksi antar manusia dengan satwa liar endemik. Untuk menjaga agar interaksi tersebut tidak berujung dalam konflik, maka diperlukan desain yang dapat memfasilitasi koeksistensi antar manusia dengan wildlife dalam lahan multifungsi. Namun, masih banyak studi mengenai koeksistensi yang menekankan pada ancaman yang akibat satwa liar pada perbatasan tersebut sehingga diperlukan pendekatan baru. Menurut Carter dan Linell (2016), sebuah pendekatan berkelanjutan yang dinamis, dimana manusia dan wildlife beradaptasi bersama untuk berbagi lahan dan aktivitas manusia diatur guna menjaga populasi wildlife yang masih dapat bertahan dengan tingkat risiko yang dapat ditoleransi. Koeksistensi bukan berarti hidup berdampingan tanpa risiko, melainkan hidup dengan toleransi terhadap risiko dan kontrol.
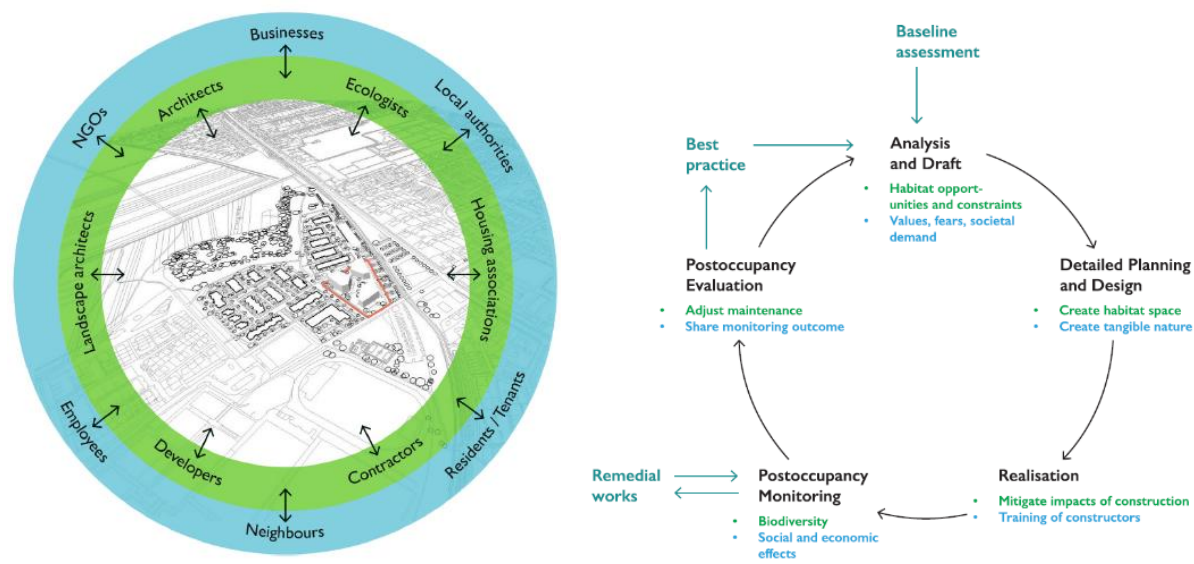

Gambar 6. Diagram pendekatan desain wildlife-inclusive urban design. Sumber: Apfelbeck et al, 2020 
Menurut riset konsep urban design oleh Apfelbeck et al. (2020), Wildlife-inclusive urban design berfokus pada perencanaan spesifik pada proyek dan tim interdisiplin yang tidak hanya mempelajari kebutuhan manusia, tetapi juga mementingkan kebutuhan satwa liar dan habitatnya. Pendekatan wildlife-inclusive urban design tidak seperti upaya konservasi konvensional yang menghindari membangun di habitat satwa liar bersangkutan. Fokus dari konsep ini adalah membentuk kesempatan untuk habitat baru pada tapak terpilih. Implementasi konsep ini dapat meningkatkan area habitat baik bagi manusia dan satwa liar dengan integrasi green infrastructure perkotaan (Zhou, Pickett, \& Cadenasso, 2017).

Prinsip ini dapat membantu mengkompensasi habitat loss dan konflik akibat perkembangan urban lewat penggunaan lahan bersama yang efektif. Selama ini, lokasi target konservasi wildlife dijauhkan dari kehidupan sosial manusia sehingga hilangnya rasa tanggung jawab terhadap keberlangsungan hidup satwa liar. Bila mengintegrasi lokasi konservasi dengan kehidupan sosial manusia, dapat terbentuk lokasi dimana manusia dan satwa liar dapat menjadikan satu sama lain sebagai elemen sosial sehari-hari, sehingga terbentuk suatu ikatan baru antar yang diharapkan dapat mengubah persepsi negatif manusia terhadap satwa liar, sehingga juga dapat meningkatkan keberhasilan konservasi bila diperlukan.

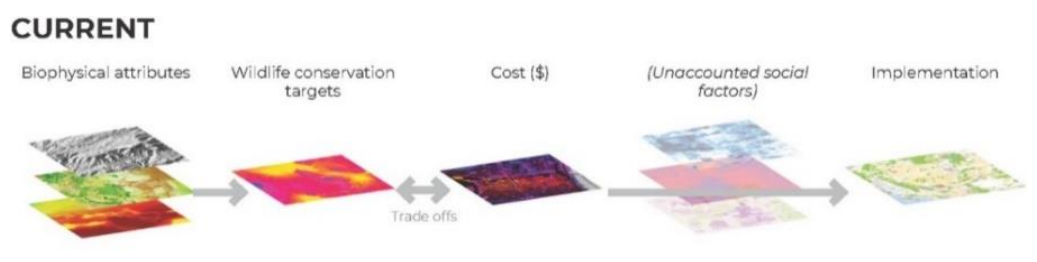

\section{INTEGRATED}

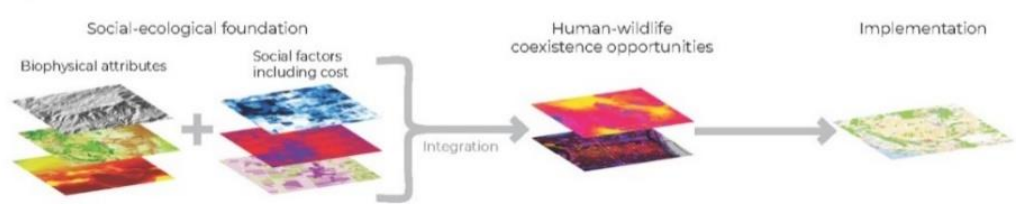

Gambar 7. Ilustrasi konseptual mengenai 2 pendekatan spasial yang berbeda dalam strategi koeksistensi manusia dengan satwa liar.

Sumber: Carter et al, 2020

\section{METODE}

\section{Metode Perancangan Bioinspired}

Metode desain yang digunakan dalam proyek ini berupa bioinspired design. Menurut the Biomimicry Institute (2021), bioinspired design merupakan kategori pendekatan desain yang menggunakan biologi sebagai sumber solusi dan mencangkup 3 subkategori yaitu biomimikri, bioutilisasi, dan biomorfisme. Biomimikri merupakan pendekatan desain yang mendekatkan fungsi rancangan ke fungsi yang ditemukan pada alam. Bioutilisasi merupakan pendekatan desain yang mengimplementasikan alam ke dalam rancangan. Sementara biomofisme merupakan metode desain yang meniru rupa yang ditemukan pada alam. Dalam proyek ini, ketiga subkategori bioinspiration diterapkan secara bergantian dan inspirasi desain diperoleh dari perilaku dan kecerdasan intrinsik Orangutan dalam konteks berhuni di kanopi hutan rimba.

\section{Metode Pengumpulan Data}

Data yang digunakan dalam proyek ini adalah data sekunder yang diperoleh dari berbagai sumber literatur dan kajian. Data sekunder ini digunakan dalam penyusunan proposal, studi preseden, serta memilih dan menganalisis tapak. 


\section{DISKUSI DAN HASIL}

\section{Pemilihan dan Analisis Tapak}

Untuk menyesuaikan konteks proyek dengan isu yang diangkat, kawasan yang terpilih sebagai lokasi proyek adalah Samboja Lestari, Samboja, Margomulyo, Kutai Kartanegara, Kalimantan Timur. Samboja Lestari merupakan sebuah hutan lindung yang dimiliki organisasi non-profit swasta yaitu BOSF (Borneo Orangutan Survival Foundation) yang bergerak dalam konservasi Orangutan Borneo dan kelestarian hutan tropis di Kalimantan. Samboja Lestari dapat diakses lewat tol Balikpapan-Samarinda exit Samboja, yang kemudian terhubung dengan jalan lokal Samboja Lodge.

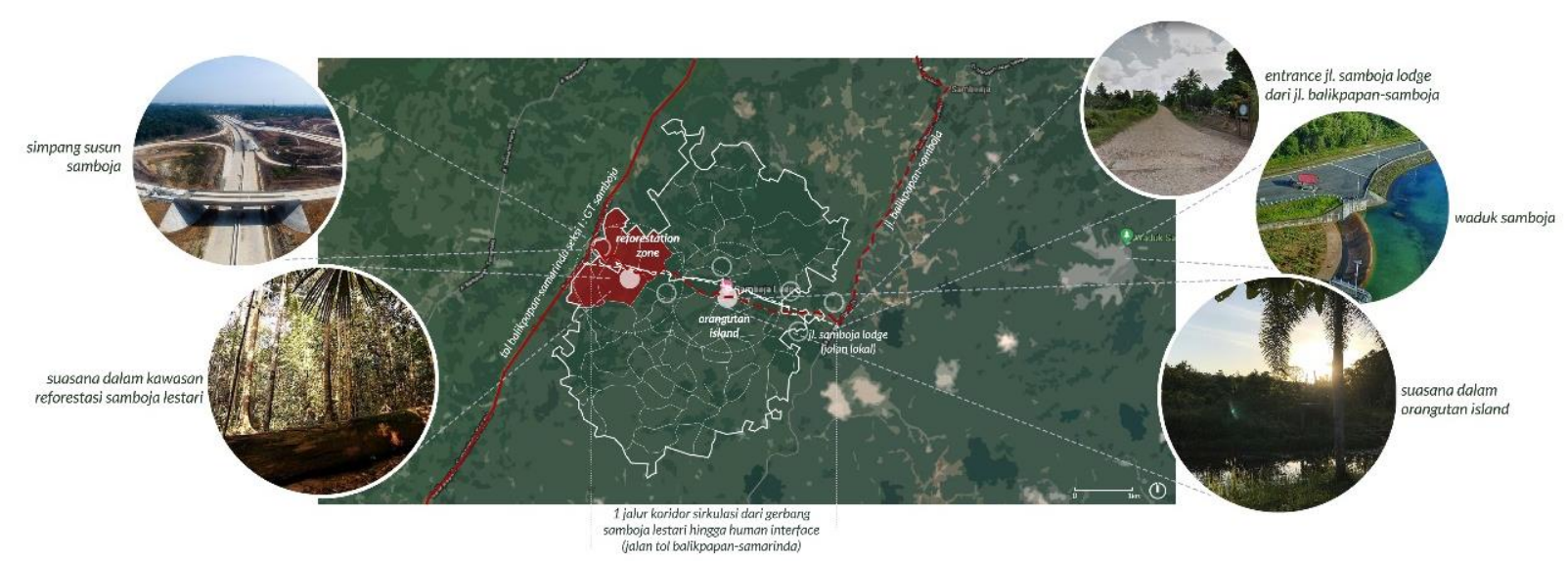

Gambar 8. Letak Samboja Lestari terhadap Jalan Tol Balikpapan-Samarinda dan lingkungan sekitarnya.

Sumber: Google (dengan olahan penulis), 2021

Samboja Lestari terdiri dari 3 zona utama. Zona terluar adalah area buffer kebakaran hutan dan sumber pemasukan warga lokal berupa perkebunan Arenga pinnata. Zona berikutnya merupakan area reforestasi untuk konservasi spesies umum. Zona terdalam merupakan zona konservasi spesies terancam punah, pusat penelitian dan pendidikan, arboretum, serta pusat relawan dan ekoturisme. Zona yang dipilih sebagai lokasi proyek adalah zona reforestasi dan zona konservasi.

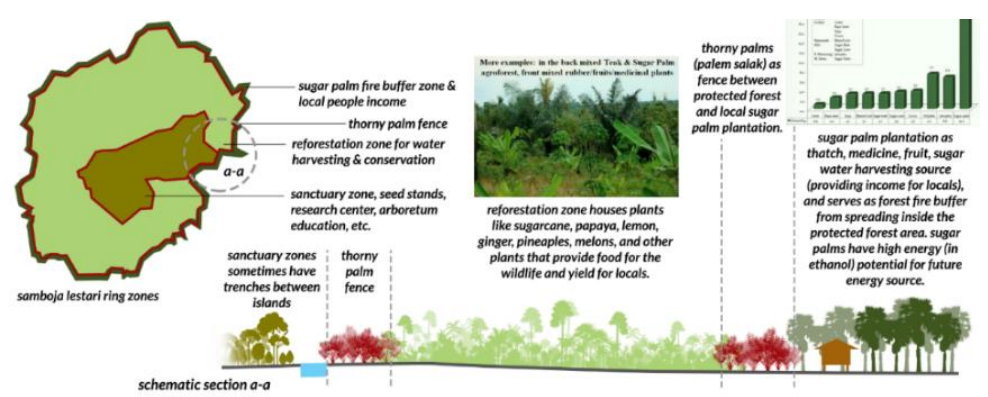

Gambar 9. Zona-zona pada Samboja Lestari dengan potongan skematik. Sumber: Penulis, 2021 


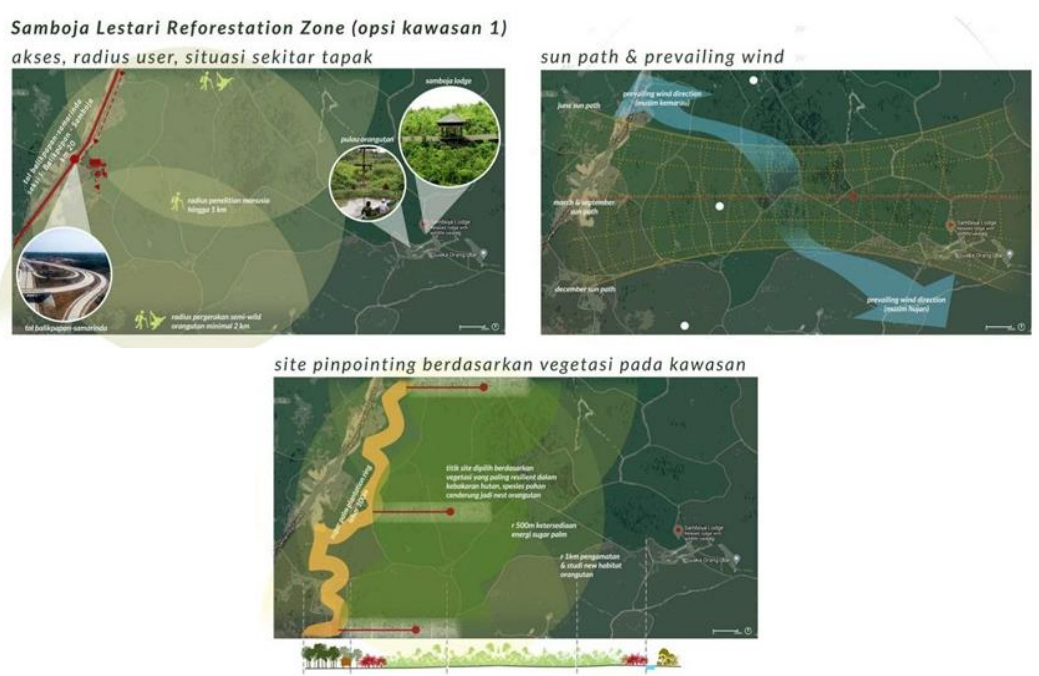

Gambar 10. Analisis tapak pada zona reforestasi dalam Samboja Lestari. Sumber: Google maps (dengan olahan Penulis), 2021
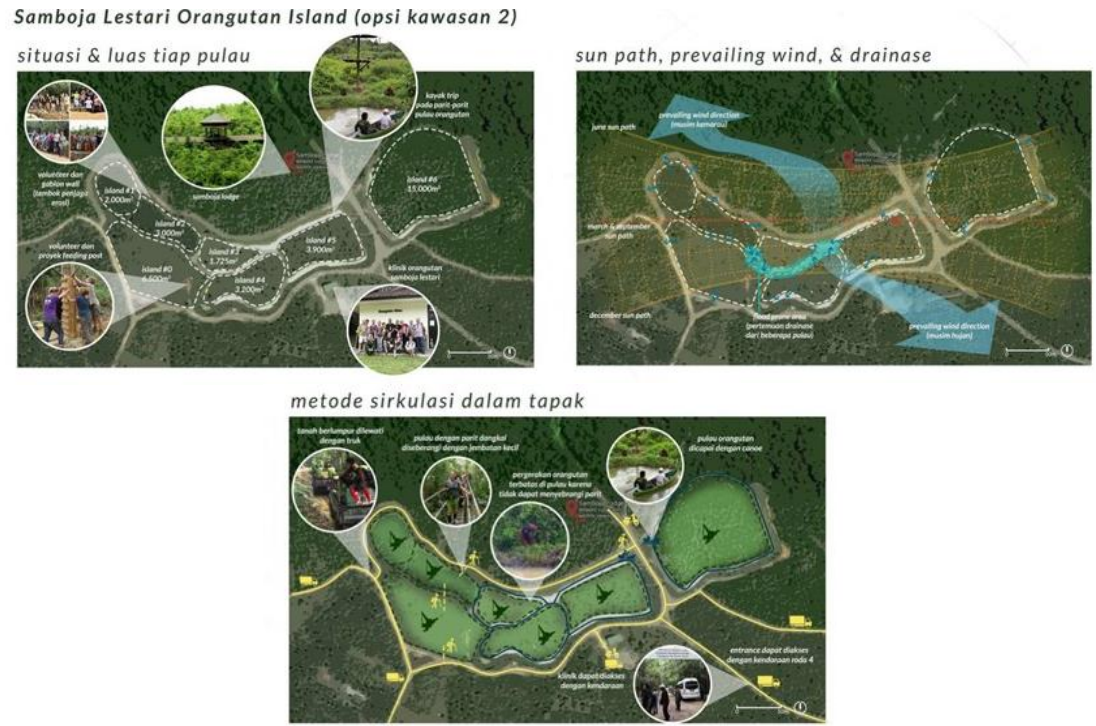

Gambar 11. Analisis tapak pada zona konservasi dalam Samboja Lestari. Sumber: Google maps (dengan olahan Penulis), 2021

\section{Prinsip Program}

Guna meningkatkan kepekaan manusia terhadap upaya konservasi Orangutan Borneo, program kohabitasi antar manusia dan satwa berlandaskan 3 jenis prinsip program. Program riset ditujukan untuk para peneliti dengan tujuan mempelajari lebih dalam kehidupan orangutan agar dapat meningkatkan kesuksesan konservasi. Program rekreasi ditujukan pada relawan dan ekoturis dari BOSF dengan tujuan mendekatkan kembali manusia dengan alam sehingga memberikan dampak positif bagi pengunjung dan satwa liar lokal. Program edukasi ditujukan pada pelajar pada IKN baru dengan tujuan menanamkan pengetahuan dan kepedulian konservasi Orangutan Borneo pada generasi muda. 


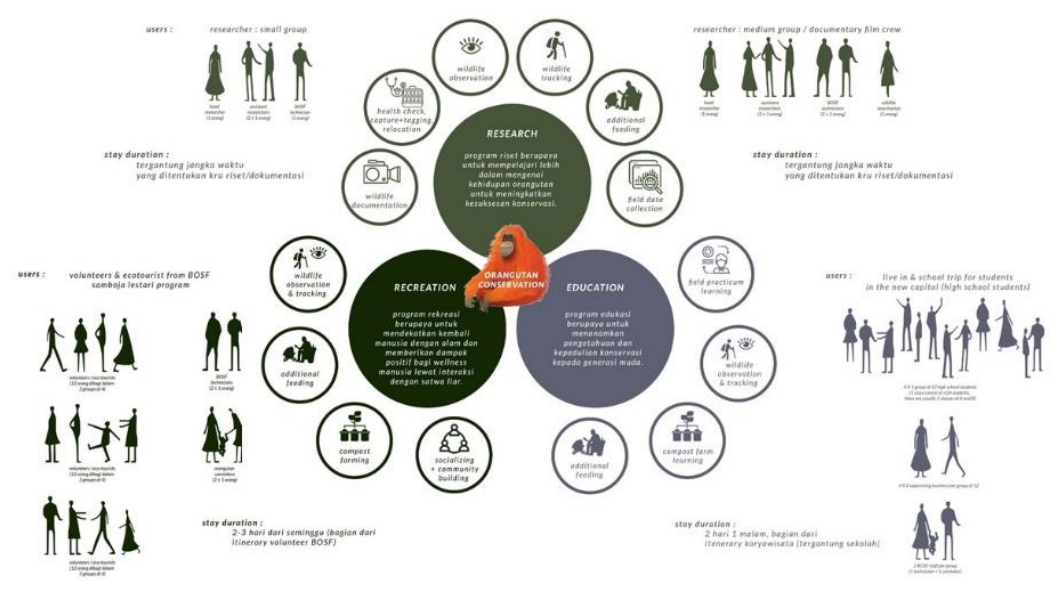

Gambar 12. Prinsip program dengan misi utama meningkatkan keberhasilan konservasi Orangutan Borneo di Samboja Lestari dengan target pengguna. Sumber: Penulis, 2021

\section{Konfigurasi Massa}

Untuk mengakomodasi program yang ditawarkan, terbentuk konfigurasi massa yang sesuai dengan keperluan masing-masing program aktivitas dan kapasitas pengguna. Konfigurasi dan massa terbentuk lewat pendekatan bioinspired dari perilaku Orangutan.

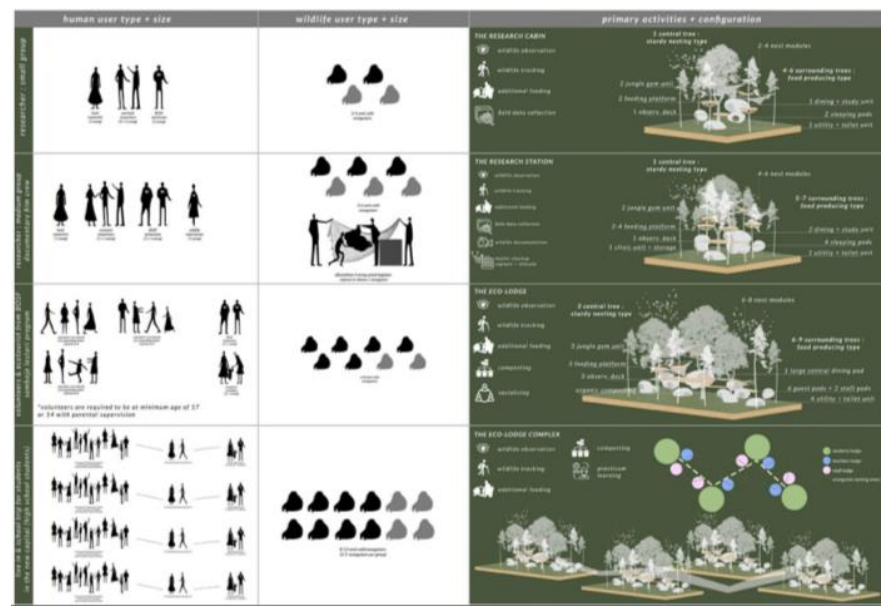

Gambar 13. Konfigurasi massa berdasarkan 4 jenis user prinsip program yang berbeda.

Sumber: Penulis, 2021

Proyek dengan konfigurasi program riset bertempat pada zona reforestasi. Hal ini sejalan dengan misi BOSF untuk merumahkan orangutan unreleasable di alam yang terkontrol. Sementara proyek dengan konfigurasi program rekreasi dan edukasi bertempat pada pulau rehabilitasi orangutan di dalam zona konservasi.
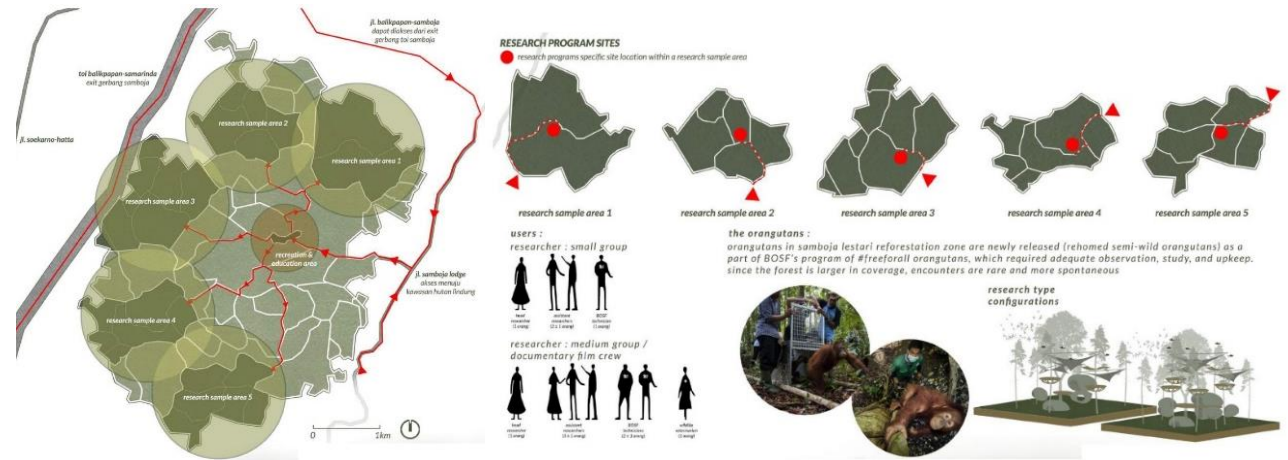

Gambar 14. Letak tapak proyek dengan program riset.

Sumber: Penulis, 2021 

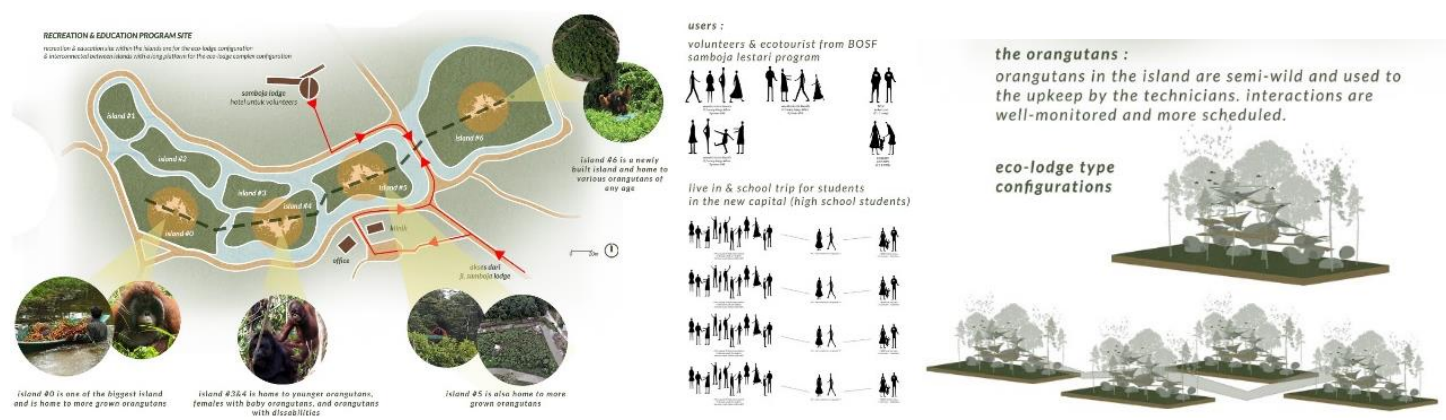

Gambar 15. Letak tapak proyek dengan program rekreasi dan edukasi. Sumber: Penulis, 2021

\section{Alur Kegiatan berdasarkan Program pada Hasil Rancangan}

Berdasarkan program yang telah disusun, terdapat dua jenis alur kegiatan secara garis besar pada konfigurasi massa yang terbentuk.
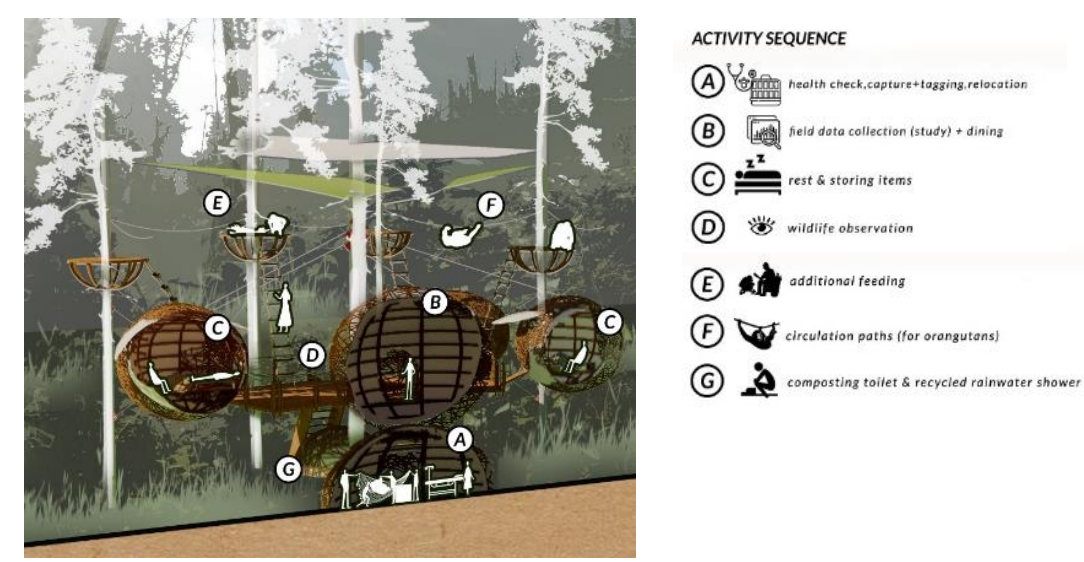

Gambar 16. Alur kegiatan pada hasil rancangan berdasarkan program riset Sumber: Penulis, 2021

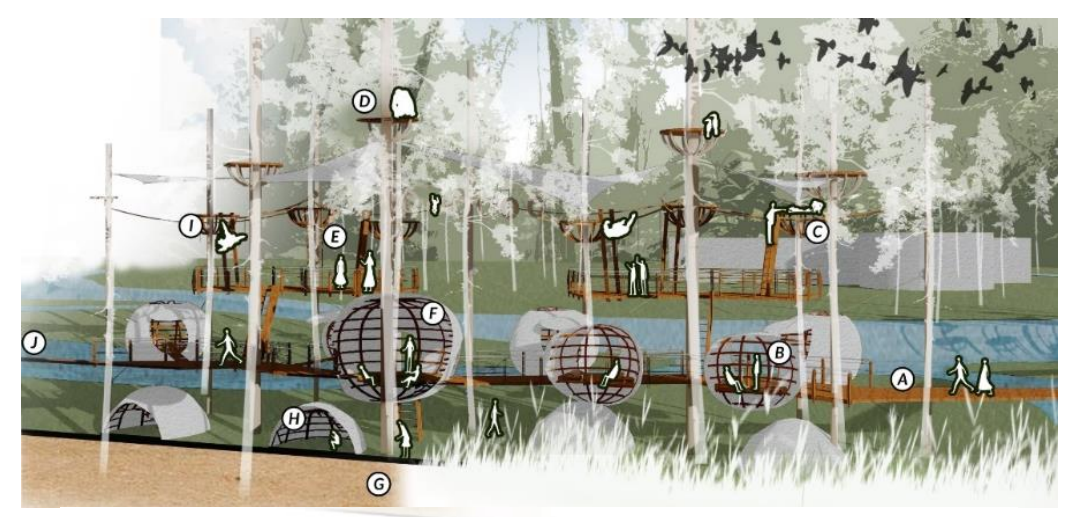

ACTIVITY SEQUENCE
(A)
(F) 8
(B) $\stackrel{\mathbf{z}^{\mathbf{z}}}{=}$ rest s storing titems
(C)
(C) odditional teeding
(A) 1
(D) 1 perching / scouting plattorm ffor willitife)
(1) 进
(E) 常 willifie observation
(1) क्र

Gambar 17. Alur kegiatan pada hasil rancangan berdasarkan program rekreasi dan edukasi. Sumber: Penulis, 2021 


\section{KESIMPULAN DAN SARAN}

\section{Kesimpulan}

Pembangunan IKN baru di Kutai Kartanegara, Kalimantan Timur, yang mencangkupi kawasan Hutan Lindung Samboja Lestari dapat menimbulkan terganggunya upaya konservasi Orangutan Borneo, spesies endemik Kalimantan yang telah berada pada IUCN Red List dalam kategori endangered (terancam punah). Dengan teori spasial baru yang mengintegrasi ruang kehidupan manusia dengan ruang kehidupan satwa liar, terbentuk kesempatan untuk koeksistensi bagi manusia dan Orangutan pada Samboja Lestari.

Dengan studi data-data mengenai Orangutan dan lingkungan Samboja Lestari, diperoleh program kohabitasi antar manusia dan satwa liar yang diharapkan dapat membantu upaya konservasi Orangutan Borneo sambil menerapkan prinsip koeksistensi antar manusia dan satwa liar.

\section{Saran}

Desain yang berlokasi di Samboja Lestari dapat diusulkan ke organisasi yang berkaitan untuk menjadi pelengkap fasilitas konservasi Orangutan, terutama kepada organisasi BOSF (Borneo Orangutan Survival Fund) yang selama ini melakukan program konservasi di hutan lindung tersebut. Programprogram yang diusulkan juga dapat diintegrasikan dengan masterplan IKN baru dan menambah daya tarik area eco-wisata Orangutan.

\section{REFERENSI}

Abram et al. (2015). Mapping perceptions of species' threats and population trends to inform conservation efforts: the Bornean orangutan case study [Electronic Version]. Diversity and Distributions, 21(5), 487-499.

Ancrenaz et al. (2016). Pongo pygmaeus. The IUCN Red List of Threatened Species 2016: e.T17975A123809220. Diunduh pada tangal 25 Maret 2021 dari https://www.iucnredlist.org /species/17975/123809220

Apfelbeck et al. (2020). Designing wildlife-inclusive cities that support human-animal co-existence [Electronic Version]. Landscape and Urban Planning, 200(1), 1-11.

Biomimicry Institute. (n.d.). What is Biomimicry?. Diunduh pada tanggal 4 Juli 2021 dari https://biomimicry.org/what-is-biomimicry/

Carter, N. dan Linnell, J. (2016). Co-Adaptation Is Key to Coexisting with Large Carnivores [Electronic Version]. Science \& Society, 31(8), 1-4.

Clements, Frederic E., dan Victor E. Shelford. (1939). Bio-ecology [Electronic Version]. New York: J. Wiley \& Sons, Inc.

Dunn, Margery G. (1993). Exploring Your World: The Adventure of Geography [Electronic

McManus, P. (2009). International Encyclopedia of Human Geography [Electronic Version]. New York: Elsevier Science.

Morton, S. \& Hill. (2014). Biodiversity: Science and Solutions for Australia [Electronic Version]. Australia: CSIRO Publishing.

Nyhus, Philip J. (2016). Human-Wildlife Conflict and Coexistence [Electronic Version]. Annual Review of Environment and Resources, 41(1), 143-171.

Russon et al. (2009). Orangutans: Geographic Variation in Behavioral Ecology and Conservation [Electronic Version]. Oxford: Oxford University Press

Sudarsono. (2005). Taksonomi Tumbuhan Tingkat Tinggi [Electronic Version]. Malang: Universitas Negeri Malang

Wich et al. (2012). Hunting of Sumatran Orang-utans and its importance in determining distribution and density [Electronic Version]. Biological Conservation, 146(1), 163-169.

Zhou, Pickett, dan Cadenasso, Mary. (2017). Shifting concepts of urban spatial heterogeneity and their implications for sustainability [Electronic Version]. Landscape Ecology, 32(1), 1-16. 